\title{
COMMUNICATIVE FOREIGN LANGUAGE TEACHING: SUGGESTED CLASSROOM PROCEDURE FOR TEACHING SPEAKING
}

\author{
Zulhermindra \\ Program Studi Tadris Bahasa Inggris, Jurusan Tarbiyah STAIN Batusangkar \\ Korespondensi: J1. Kompleks Arai Pinang 1 Kuburajo Lima Kaum Batusangkar \\ e-mail: zulhermindra@yahoo.com
}

\begin{abstract}
Teaching speaking to students at any level seems to be a big problem to English teachers. As a result, this skill seems to be ignored. Though, some of the teachers have tried hard to teach this skill, the result does not reflect the competency that the students are supposed to master. This is due to the inappropriate techniques and classroom procedures applied in the classroom. Consequently, the learning processes tend to be boring. This paper is intended to introduce some suggested techniques and a sample classroom procedure in terms of communicative language teaching.
\end{abstract}

Kata kunci: CLT, speaking, classroom procedure, teaching, technique

\section{INTRODUCTION}

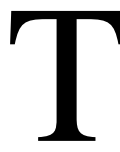
The basic function of a language is for communication. Therefore, the teaching of English and other foreign languages, at any level, should facilitate the students with the opportunity to use the languages for communication, both in spoken and written forms. By means of the languages, students are expected to be able to express their ideas and feelings, share experiences and transfer knowledge they have to other people of different mother tongues. In addition, by mastering a foreign language, the students will be able to take part in more global communication, such as in international communication as well as in global competition which in turn will be beneficial for their study and career opportunity in the future. It is undeniable that students with better command in English, for example, will be able to get current information for their study both from printed or electronic resources. Furthermore, greater opportunities are also available to those who are good in spoken English.

To be able to use English for communication, both spoken and written, students should be provided with basic skills of English, such as listening, speaking, reading and writing, and other supporting language components, such vocabulary, grammar, pronunciation, etc. By mastering those basic language skills and components, students are expected to be able to perform communication well and in turn the aim of language teaching can be achieved.

Dealing with one of those basic skills, that is speaking; there are some teachers who have tried to encourage students to speak English in their class. However, the techniques that they apply do not seem to interest and challenge the students. For example, the teachers tend 
to give the students a dialogue, ask them to memorize the lines, change some words of the dialogue suitable with the situation and perform in front of the class. As a result, students do not know what they are presenting the dialogue for. Furthermore, dialogue is not natural because it is created based on the model given, not the real situation.

Dealing with the above problem, Ur (2000) points out that there are some potential problems with speaking activities faced by students in the classroom. Those problems are: 1) inhibition: worried about making mistakes, fearful of criticisms or loosing face, etc. 2) nothing to say: cannot think of anything to say - no motive express themselves beyond the guilty feeling that they should speaking. 3) low or uneven participation: tendency of some learner to dominate, while other speaks very little or not at all, and 4) mother-tongue used: tendency of all or a number of learners who share the same mother tongue not to use the target language since they feel unnatural not exposed to talk in the target language,

Based on the problems discussed above, classroom teaching procedure should desgned in such a way in which the target of curriculum can be obtained, natural speaking activities can be performed as well, while joy and fun are still there. Therefore, this paper would like to propose some suggested techniques for teaching speaking communicatively and classroom activities as well that the teacher may apply in their teaching.

\section{COMMUNICATIVE LANGUAGE TEACHING}

Communicative language teaching (CLT) is the generally accepted norm in the field of second language teaching. CLT suggests communicative language and language acquisition, and the app- roach proposes way for learners to internalize a second language and to experiment in a classroom context. Therefore, the classroom context is used to create activities to teach students how to react in a real world situation, not to fake real-world situations. The basic features of CLT are:

1. An emphasis on learning to communicate through interaction in the target language.

2. The introduction of authentic texts into the learning situation (Authentic material is a must, because students cannot extrapolate to the real world from their learning on made-up material)

3. The provision of opportunities for learners to focus not only on language, but also on the learning process itself.

4. An enhancement of the learner's own personal experience as important contributing elements to classroom learning.

5. An attempt to link classroom language learning with language activation outside the classroom. (Brown, 2001)

In addition, at the level of language theory, Communicative Language Teaching has a rich, if somewhat eclectic, theoretical base. Some of the characteristics of this communicative view of language follow:

1. Language is a system for the expression of meaning.

2. The primary function of language is for interaction and communication.

3. The structure of language reflects its functional and communicative uses.

4. The primary units of language are not merely its grammatical and structural features, but categories of functional and communicative meaning as exemplified in dis- 
course.

Furthermore, Galloway (1993) adds that

Communicative language teaching makes use of real-life situations that necessitate communication. The teacher sets up a situation that students are likely to encounter in real life. .... The real-life simulations change from day to day. Students' motivation to learn comes from their desire to communicate in meaningful ways about meaningful topics.

According Breen and Candlin (2010), dealing with the roles of learner in CLT class, the emphasis in Communicative Language Teaching on the processes of communication, rather than mastery of language. In addition, there are roles that are assumed for teachers in Communicative Language Teaching, the importance of particular roles being determined by the view of CLT adopted. Breen and Candlin (2010) describe teacher roles in the following terms:

The teacher has two main roles: the first role is to facilitate the communication process between all participants in the classroom, and between these participants and the various activities and texts. The second role is to act as an independent participant within the learning-teaching group.

In addition to the idea above, Cheng (2010) emphasizes that

The teacher's main function is to initiate activities and once he is satisfied that they know exactly what they are to do, he will be as unobtrusive as possible, intervening only when it is really necessary. He will therefore be the guide and facilitator rather than the controllerin-chief. All in all, this makes for a more relaxed classroom atmosphere.

Finally, dealing with types of learning and teaching activities, accord- ing Breen and Candlin (2010), the range of exercise types and activities compatible with a communicative approach is unlimited, provided that such exercises enable learners to attain the communicative objectives of the curriculum, engage learners in communication, and require the use of such communicative processes as information sharing, negotiation of meaning, and interaction. Classroom activities are often designed to focus on completing tasks that are mediated through language or involve negotiation of information and information sharing.

\section{TEACHING SPEAKING COM- MUNICATIVELY IN EFL CLASS: SOME SUGGESTED TECHNIQUES AND CLASSROOM ACTIVITIES}

Before coming to the discussions of how to teach speaking communicatively in EFL setting, the nature and procedures of teaching speaking will be elaborated first.

\section{Teaching Speaking}

According Widdowson (1984) speaking is the active productive skill and makes use of oral communication. Communication through speaking is commonly performed by face-to-face interaction and usually occurs in form of dialogue or other forms of verbal exchange. Bygate (1980) points out that the speaking is often thought of as a popular form of expression. It means that speaking can help one to express his ideas and thoughts better than other skills. People also assume that one can communicate if he can speak in that language well. Consequently, if one cannot speak English, he is assumed to be unable to communicate in that language. It can be understood that why speaking skills cannot be ignored in the teaching of the language. 
In addition to the above ideas, according to Brown (2001) teaching speaking provides speaking skills, such as fluency, accuracy, and interaction. Harmer (1984:45). There are major stages, namely introducing new language, practicing and having communicative activities. Dealing with how to teach speaking in the classroom, Cunningsworth (1984) points out that approach to teaching English as foreign language should stress the importance of learning through using language and give the learners frequent opportunities to interact with each other and with teacher in natural situation. It can be concluded that technique or approach applied of teaching English should give the chance to the students to express their ideas and thoughts to other in one hand and try to understand the ideas conveyed on the other hand. Furthermore, this technique should be used in natural situation so that the students understand how to use particular expression in particular situation. By doing this, it is expected that students can use the language for daily activities.

Talking about the nature of speaking activities, Nolasco (1987) elaborates the characteristics of the speaking of native speaker, that is, what actually they do when they are speaking, as follow: (1) they share meaningful information, (2) they take turn, (3) they use gestures and body language to emphasize, and (4) they use stresses and intonation. In line with this, Farrant (1989) adds that when one communicates, there are commands that the message (what the speaker wants to way) be put into suitable code, such as body language as gestures and transmitted by the sender (the speaker) to the listener (receiver) using appropriate media (that is, language). It is clear that in communication; especially speaking, message is the most important thing to be considered by the speaker and listen- er. If the speaker cannot convey his ideas or the listener cannot understand the ideas of the speaker, the communication does not exist. It means the learner should try (or be trained) hard to express his thought whatever ways he can use. On the other hand, the listener also should try to do the same thing to understand the ideas that the speaker wants him to. Furthermore, according to the ideas above, in order to convey the ideas, the speaker should not always use words or verbal expression only, but also other ways, such as gestures or body language and facial expressions. Therefore, the speaker should not be frustrated because he does not have enough vocabularies to express what he wants.

\section{Procedures to Teaching Speaking}

According to Harmer (1984) there are three major stages in teaching a language, namely introducing new language, practicing and having communicative activities.

\section{Suggested Classroom Procedure}

This part proposes some techniques and classroom activities that the EFL teachers may apply in their classrooms. The procedure can be simply illustrated below:

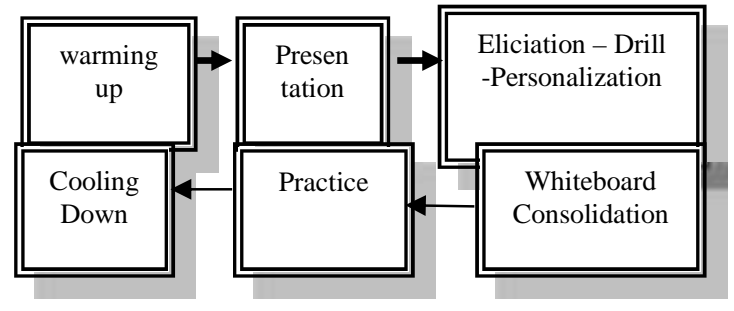

The stages of the procedures are discussed in detail below:

\section{Warming Up}

The main purpose of this stage is to review previous topic and/or to break the ice. The are several techniques or activities that may be useful in this stage. Those techniques/activities are: 
2Chained Message

\& Mingle

Moving seats

$\&$ Group competition

\& Group Cooperation

$\approx$ Language games

\section{Presentation}

The main purpose of this stage is to introduce or to presenting the topic that the students will deal with. There are some techniques that a teacher may apply, such as:

Supplied dialogue

es Completing dialogue

2s Read and Run

2s Unjumbled dialog

3. Elicitation, Personalization and Meaningful Drill

This stage consists of three inseparable activities:

Elicitation: the students pick up the language points to be studied which is found in the presentation stage (i.e. Is it alright if I ....).

Meaningful drill: the students are drilled by using the language points they have elicited before (i.e. Is it alright if I .../Can I .../Am I allowed to ..../ etc.).

Personalization: the students in turns practice subconsciously using the language points they elicited in the presentation stage (i.e. Roni, is it alright if I come to your house tonight? Or Dini, would mind if I used your calculator? Etc.

\section{Whiteboard Consolidation}

In this stage, the teacher writes on the board the language points which has been elicited, meaningfully drilled and personalized by the student. This is very essential since this stage provides the students with a clear picture about what they are learning.
Common Expressions for Asking and Giving Advice

\begin{tabular}{|c|c|c|}
\hline $\begin{array}{l}\text { Asking for } \\
\text { Permission }\end{array}$ & Granting & Refusing \\
\hline $\begin{array}{l}\text { Can I ...? } \\
\text { May I ...? } \\
\text { Is all right if I } \\
\ldots \text { ? } \\
\text { Is OK if I ...? } \\
\text { Am I allowed to } \\
\ldots \text { ? } \\
\text { Am I permitted } \\
\text { to ...? } \\
\text { Do you mind if I } \\
\ldots \text { ? } \\
\text { Would you mind } \\
\text { if I ...(ed)? }\end{array}$ & $\begin{array}{l}\text { Sure. } \\
\text { Why not? } \\
\text { Certainly? } \\
\text { No } \\
\text { problem. } \\
\text { My } \\
\text { pleasure. } \\
\text { Go ahead } \\
\text { Not at all. }\end{array}$ & $\begin{array}{l}\text { I'm } \\
\text { afraid } \\
\text { you can't } \\
\text { You'd } \\
\text { better not } \\
\text { to }\end{array}$ \\
\hline
\end{tabular}

\section{Controlled and Freer Practice}

The main purpose of this stage is to provide students with opportunities to practice the language points they have already learnt. In controlled practice, the teacher may give practice to students by referring the exercise taken from relevant resources while in freer practice, the students may bring the students to the more naturalistic use of the language points. There several techniques/activities that the teacher may assign the students to practice, such Talk show, Mingle, Reporting, Press Conferencing, Pair Conversation, Speech, Simulated Job interview, etc.

\section{Cooling Down}

The aim of carrying out this stage is to provide the students with relaxing activities that may relate or nothing to do with the topic just learned. Techniques/Activities that can be used are: language games (crossword puzzle, riddle, etc), songs, poetry recitation, etc. 


\section{A SAMPLE FOR CLASSROOM APPLICATION}

This part presents how this techniques and procedure work in the classroom.

\section{Warming Up:}

This part is intended to review the topic that had been discussed in previous meeting. The details are presented below:

Topic : Daily Routines

Purpose : To review students' previous topic

Technique: Mingle

Procedure :

- Distribute the worksheet to the students.

- Explain what they should and should not do

- Allow them to accomplish the task in a limited time.

- Discuss the result.

\begin{tabular}{|l|l|l|}
\hline No & $\begin{array}{l}\text { Find someone } \\
\text { who .... }\end{array}$ & Name \\
\hline 1. & $\begin{array}{l}\text { wakes up at 6 every } \\
\text { morning. }\end{array}$ & $\ldots \ldots \ldots$. \\
\hline 2. & $\begin{array}{l}\text { has breakfast at } \\
\text { school everyday }\end{array}$ & $\ldots \ldots \ldots$. \\
\hline 3. & never has breakfast & $\ldots \ldots \ldots$. \\
\hline 4. & $\begin{array}{l}\text { has dinner with the } \\
\text { family every evening }\end{array}$ & $\ldots \ldots \ldots \ldots$ \\
\hline 5. & etc. & $\ldots \ldots \ldots$. \\
\hline
\end{tabular}

\section{Presentation}

This part is aimed at providing the students with a model of the text that contains the expressions they are going to study.

Topic : Asking and giving advice/suggestion
Purpose: To provide the students with some expressions or asking and giving advice/suggestion

Technique: Completing the dialogue

Procedure:

1. Show students a picture and ask their opinions about what happens to the person in the picture.

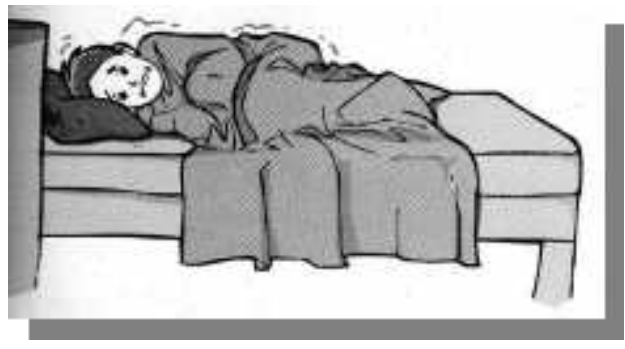

2. Divide the students into two groups: A and B

3. Ask the students to sit in groups in line and face the other group.

\begin{tabular}{|l|l|l|l|l|l|l|l|l|l|}
\hline $\mathbf{A}$ & $\mathbf{A}$ & $\mathbf{A}$ & $\mathbf{A}$ & $\mathbf{A}$ & $\mathbf{A}$ & $\mathbf{A}$ & $\mathbf{A}$ & $\mathbf{A}$ & $\mathbf{A}$ \\
\hline
\end{tabular}

\begin{tabular}{|l|l|l|l|l|l|l|l|l|l|}
\hline $\mathbf{B}$ & $\mathbf{B}$ & $\mathbf{B}$ & $\mathbf{B}$ & $\mathbf{B}$ & $\mathbf{B}$ & $\mathbf{B}$ & $\mathbf{B}$ & $\mathbf{B}$ & $\mathbf{B}$ \\
\hline
\end{tabular}

4. Distribute the worksheet face down to the students.

a. Warn them not to open until they are allowed to.

b. Ask them if they have some problems with vocabulary.

c. Explain the difficult words (if any).

5. Explain what they should and should not do

6. Allow them to accomplish the task in a limited time.

7. Discuss the result.

a. Text Model

$$
\begin{array}{ll}
\text { Joan } & : \text { Hello } \\
\text { Betty } & :------------- \\
\text { Joan } & : \text { Terrible } \\
\text { Betty } & :--------------
\end{array}
$$

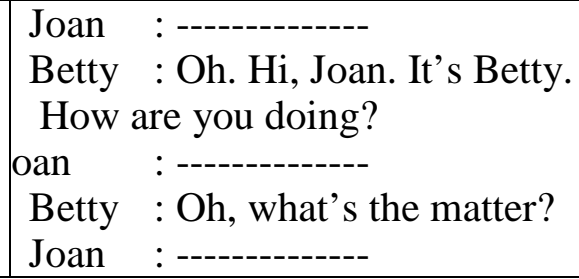




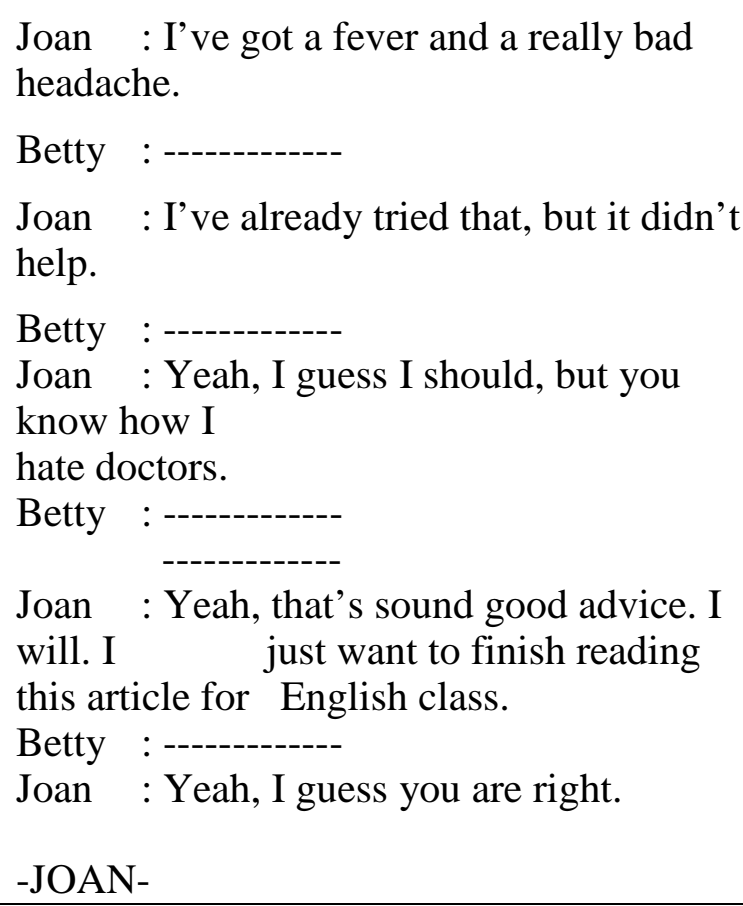

\section{b. Elicitation, personalization and whiteboard consolidation}

1. Ask the students following questions to check their comprehension toward the text.

- Where did the conversation take place? Why?

- What was the relationship between the persons?

- Tell me about Joan. Was there something wrong about her?

- Was there anything that Betty can do to help her? How?

- What did Betty advice?

take some aspirin
go to the health center
and see a doctor.
stay in bed at least
not try to do any work
right now
lie down and take it
easy for a while.

- What did Betty say to give her advice to Joan?

Why don't you ...

You should ...

You'd better...

If I were you, I'd ...
Betty : Oh. That's too bad. Why

don't you take some aspirin?

Joan : -------------

Betty : Well, maybe you should go to the health center and see a doctor.

Joan

Betty : Well, you'd better stay in bed at least. You really sound sick.

Joan : --------------

Betty : You know, you really shouldn't try to do any work right now. If I were you, I just lie down and take it easy for a while.

Joan : --------------

-BETTY-

2. Drill the students chorally and individually by combining the expressions and advice.

Example: Teacher:

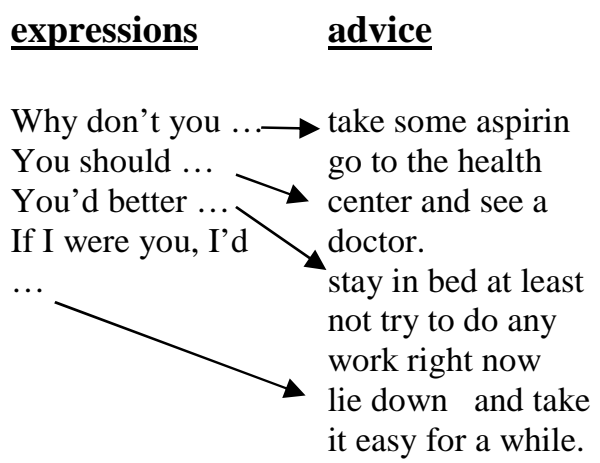

3. Allow the students to practice the expressions in turns and continuously so that everybody has a chance to express and respond.

(i.e. Teacher: Andi, I got a headache. What should I do?

Andi: You should take some aspirin, etc.

Andi: Susi, my mother got angry with last night.

Susi: You'd better say sorry to your mom.

Etc.) 
4. Present summarizing table by adding more similar expressions for asking and giving advice:

\begin{tabular}{cc}
\hline Asking advice & \multicolumn{1}{c}{$\begin{array}{c}\text { Giving } \\
\text { advice }\end{array}$} \\
\cline { 2 - 2 } - What should I & - You \\
do? & should/ \\
- What do you & ought (not) \\
suggest? & $\ldots$. \\
- What do you & - I suggest/ \\
advise? & advise/ \\
- What do you & recommend \\
recommend? & you (not) to \\
- What would you & $\ldots$. \\
do if were me? & - If I were \\
- What suggestion & you, I'd \\
can you give? & (not).... \\
- What advice & - Why don't \\
can you share? & you .... \\
- What & - Have \\
recommendation & thought \\
can you offer? & about (not) \\
& $\ldots$. ing ? \\
& - It's better \\
& for you to \\
& $\ldots$ \\
\hline
\end{tabular}

\section{Practice}

In this part, the students are given opportunities to practice the expressions of asking and giving advice both in groups and individually.

a. Controlled Practice (JCoT)

- Distribute the paper containing problems they are supposed to solve in groups.

1. My problem is that I can't get to sleep at night. It takes me about four hours to go to sleep. Then I can't get up on time in the morning to go to school. Or if I do, I'm so tired; I can't follow the class very well. (sleepless)

2. My older brother snores and keeps me awake at night. Is there anything I can do about it? (disturbed)

3. My hair has been getting thinner over the last couple of years. Is there any way to stop my self from going bald? (thin on top)

4. People tell me that I'm very tense. I don't seem to be able to relax. I guess I worry too much about things. Can you suggest anything to help me? (uptight)

5. My father would like to give up smoking. Right now, he smokes about two packs of cigarette a day. But, it's very hard for him break the habit. Can you suggest anything? (smoker)

6. I'd like to be able to make more friends and meet more people. What advice can the panel give? (lonely heart)

- Allow them to write advice/ suggestion in phrases only.

For example: Do yoga before sleep.

b. Freer Practice (ICoT)

Technique : Talk show (Radio call in show)

Purpose : to give opportunity to the students to practice asking and giving advice/suggestion in more natural, communicative and spontaneous way

Procedure:

- Invite 5, 6 or 7 students to participate in the 'talk show' program.

- One of the students acts the host of the local radio program while the others act as the panel members of the program. These panel members are expected to give advice/suggestion toward the randomly chosen problem.

- The rest of the class act as the listeners of the program who may also share their own suggestion or call in spontaneous problems.

6. Cooling Down

- Topic : -

- Goals : to relax the students 
- Technique : : Poetry Reading (funny poetry)

\section{Thank You for Listening}

Thank you for listening, hearing me out. All my sad sorrow needed, no doubt, kindness and sharing. yours the love strong, open and caring, under my song

\section{CONCLUSION}

\section{BIBLIOGRAPHY}

Breen and Candlin. 2010. Communicative Language Teaching. Available in http://www2.vobs.at/ ludescher/Alternative\%20methods/ communicative_language_teaching .htm\#Background Retrieved January 29, 2010.

Brown, H. Douglas. 2001. Teaching by Principles: An Approach to Language Pedagogy. New Jersey. Englewood Cliff.

Bygate, Martin. 1980. Speaking Language Teaching: a Scheme for Teacher of Education. New York:

Cheng, William. 2011. Communicative Language Teaching: Theory and Practice. Available in

http://sunzi.lib.hku.hk/hkjo/view/33/330 0090.pdf. Retrived on Januari 29, 2010

Cunningsworth, Alan. 1984. Evaluation and selection of EFL teaching material. London: Heinenman Education Book, Ltd.
Teaching students to be able to speak English communicatively can be a very challenging as well as rewarding to some English teachers. However, classroom teaching activities for speaking can be very monotonous and less interesting. Furthermore, the students just perform speaking task without realizing what they are doing. This procedure promotes an interesting and communicative way of teaching speaking. This is made possible since starting from beginning (warming up), presentation, up to practice, the students have been given speaking based activities.

Farrant, J. S. 1989. Principle and practice of education. London: Longman

Galloway, Ann. 1993. Communicative Language Teaching: An Introduction and Sample Activities. ERIC Digest. ERIC Clearinghouse on Languages and Linguistics Washington DC. Available in http://www.ericdigests.org/1993/sa mple.htm Retrieved on January 29, 2010

Harmer, Jeremy. 1984. The practice of English Language Teaching. New York. Longman.

Nolasco, Rob. 1987. Conversation. Oxford University Press

Ur, Penny. 2000. A Course in Language Teaching: from Practice to Theory. Cambridge: Cambridge University Press

Widdowson, H. G. 1984. The teaching of English as Communication. London. Oxford University Press. 